\title{
Cicero on Constitution, Government and Ethics
}

\author{
Mubasher Mahdi
}

\author{
Assistant Professor of English, Government Emerson, College, Multan, Punjab, Pakistan
}

\begin{abstract}
Cicero is an important figure of philosophy in the post-Socratean tradition. He not only excels in the art of Rhetoric and oratory, but also in giving judgment on poetry to politics and keenly observing Epicurean theory of pleasure.
\end{abstract}

Like his master Aristotle, his writing style is very lucid and succinct. Various interpretations of Cicero and the translations of his work as "De Republica" or the 'Republic' clearly place him as a man whose writings are a gem of classics.

As soaked and well versed in the Greeko-Roman tradition, he also emphasized the notions of 'ETHICS' as a larger perspective of formulating not only the state, government and constitution, but also a fundamental and profound aspect of individual's concern as well as of the whole society. His typical oratory and the use of the art of Rhetoric are also only and solely not inspired, but his own. He weaves the concepts about ethics in this very typical style and background.

Essentially as a philosopher, assigning the role of philosophy in determining the several social codes, he particularly elaborates the idea of power, duty, justice and war.

His philosophy promulgates that 'ETHICS' are the bases and rightfully define the society and makes it function properly. As he allocates a substantial worth to 'Ethics', he places them at a higher pulpit and all other areas of social life under this very title. He even sees that state and government and also constitution of any state, are part of this larger study of 'ETHICS'.

The article seeks to view Cicero's thoughts on the above mentioned issues, and how he delineates the nature and function of a well run society, and its laws, keeping it in the frame of 'Ethics'. It also deals with the Ciceronian concepts and ideas of constitution and government. The article also tries to search parallelism between the Ciceronian maxims and their relevance to today's world of chaos and anarchy.

Keywords- Ethics, Constitution, Power, State Government.

\section{INTRODUCTION}

The present day chaos and anarchy need to be analysed. The only way to analyse is to look back at the writings of the philosophers of past. Their writings could provide significant thoughts, though which may be historical, but they could lead us to determine the causes of present day chaos and why we are unable to achieve peace?. Their thoughts will help us to locate our mistakes.

The fundamental concern of every society is ethics and the governance of a state in the frame of ethics. The ethics is an overwhelming concept and all other notions like, constitution, government and governance of a state are its sub-titles. From Socrates to Plato and Aristotle and then Cicero, there is a long debate about ethics, which are directly related to the laws of a state.

Cicero has also developed the most fundamental concern of every philosophy; the ethics and their interrelationship with government and constitution. In his remarkable treatises "The Republic" and "The Laws", he has thoroughly implored the above mentioned issues of philosophy and logically analyzed and elaborated them. Moreover, he has also dealt with significant systems of governments like democracy, and oligarchy. He has also given his substantial views about anarchy also.

\section{THEORY AND PRACTICE}

Cicero (2008) so comments about morals, "Yet it is not enough to possess moral excellence as a kind of skill, unless you put it into practice. You can have a skill simply by knowing how to practice it, even if you never do. Whereas moral excellence is entirely, a matter of practice". (p.4)

Cicero has emphasized the role of morals and morality. In fact, he is of the view actually that morals should be followed as a duty. The theory and practice have been the poorest adherents in every society, since the first communities were formed. We can say that individual has both the desires, the desire of good and evil. The matter is to restrict ourselves. If we perform well habitually, then we can practice morals. It is strange, that whenever an individual gets authority, he gets corrupted and exploits his authority. Even today in our different societies across the globe we can witness authoritarian role not only of leaders but also in common men, due to unjust systems of governments in various countries.

\section{PRESENT WAR}

The present day world is immersed in war, because war is being eliminated by war. This is also an unusual fundamentalism on part of the powerful nations. They have imposed war to remove their opposites, who are 
also waging war. Is there any solution to it? Is war an answer to war? We have to think about it. Though complete peace may not be prevailed, but we should think about other alternatives. Lord Buddha has said: "the only way to conquer hate is love".

\section{NOTIONS ABOUT SOCIETY}

Cicero (2008) gives the answer of the above discussion in this way, "Where does devotion come from? Who gave us our religious observances? What is the source of law, either the law of nations or this civil law of ours? From where did justice, good faith, and fair dealing come? Or decency, restraint, the fear of disgrace, and the desire of praise and honour? Or fortitude in hardship and danger? Why, from those men who have taken these values, already shaped by teaching, and either established them in customs or confirmed them in law".(p.4)

The questions raised by Cicero in the above quotation are of a great value. These questions are directly related to the governance of individuals in a community and largely in a society. He is of the view that proportionate state in a society comes when individuals show fortitude in troubles and hardships. He has also talked about virtues like decency, honour and fear of disgrace. He questions about the source of law as well; all these issues are the basics and bases of constitution and government, along with this also, that by knowing the nature of these issues we can develop a balanced society, run by rulers who also know about these valuable thoughts. Moreover, Cicero has talked about the training and teaching of the individuals, which is the most significant issue and that also related to our present time, because by educating the people, we can only extinguish the fire of in-tolerance spreaded across the globe.

Cicero (2008) further explores the nature of governance like this, "In fact Xenocrates, one of the most illustrious philosophers, when asked what his pupils got from him, is said to have answered to do of their own free will what they are compelled to do by law".(p.4)

The matter of free will and its exercise is very complicated. If we negate the law which is the state of order developed by a consensus of the whole people, or at least developed at a large pulpit, owing to traditions, norms and customs of a society, and laid down by people who believe in larger interest of a community or society or who are the intellectuals, it can lead to anarchy. In other words, we can say that law should be so which takes care of individual liberty as well.

\section{GOVERNANCE}

Further initiating the concept of governance Cicero (2008) points out "So then, the states man who, by official authority and legal sanctions oblige everyone to do what barely a handful can be induced to do by philosophy lectures, must take precedence over the teachers who theorize about such matters. What philosophy lecture is so fine that it deserves to be set above the public law and customs of a well-ordered state? For my own past, I consider what Ennius 'calls' great and commanding cities' superior to little villages and outposts; similarly, in my view, those who govern such cities by their counsel and authority are in wisdom itself far above those without experience of public affairs".(p.4)

The human history has its own course. Its movement is unpredictable. The heroes at one moment are the beggars' sight at the second moment. The fortune may play any role, but this is the greatest excuse. Every hero should forecast the events which he has to face. But, a hero never knows how he is betrayed.

\section{THE IDEA OF VALOR, COURAGE AND BRAVERY}

The corridors of power have always been filled with conspiracies all the time. The friends at one time, all of a sudden convert into foe as power has its own flair. The human history has always played a brutal role with the gigantic and brave men. The valorous, the men of swords and men of pen, the orators and the prince, fall to abyss within no time, but the marks of history now pose a question in this modern era, whether bravery is bravery or bravery is barbarism.

Talking about valour, courage, bravery, and fall of the greatest citizens, Cicero (2008) quotes so, "on that topic our opponents a Wax fluent and eloquent (in their own opinion), reeling off the disasters of eminent men and the wrong they have suffered from ungrateful citizens. Here they cite the familiar Greek examples how Miltiades, the conqueror and tamer of the Persians, before those wounds which he sustained with his face to the foe in that glorious victory were healed, breathed forth the life that had survived that enemy's onslaught in the fetters of his own compatriots, how Themistocles, cast out and warned off with threats from the country he had freed, found refuge not in the heavens of Greece which he had saved but in the shelter of that foreign land which he had brought low. Yes 
indeed, the caprice and cruelty of Athens towards her greatest citizens can be illustrated again and again. But the habit which started and multiplied there has also, we are told, spread to this sober, responsible, country of ours. One hears of Camillus' exile, the wrong done to Ahala, the resentment at Nasica, Laenes' banishment, Opinius' convictions, Metellus, departure into exile, the appallingly, cruel over throw of Gaius Marius and the murder of the supporters, and the widespread slaughter that followed shortly after. Nowadays they regularly mention my name too; and they speak even more feelingly and affectionately about my case, because (I suppose) they think they were spared to continue in their peaceful way of life as a result of my policy and peril.” (p.5)

\section{PHILOSOPHY AND PRACTICAL POLITICS}

The Art of politics is necessary for an intellectual. He should have an expertise in the field of practical politics. From outside of the arena of politics, it is easier to criticize the government and its policies, but when you become part of active politics, you have to face many odd circumstances and crises. The philosophy also emphasizes the sole of the politics and its knowledge is a must for an intellectual. This is essential because any time assistance of wise men could be taken by the ruler. The philosophy without the practical knowledge of politics is just like a boat without oars. You can drive the people in a good direction if you have any opportunity to govern them. Moreover, the philosophers are the vanguards of any society, just like orators, and their wisdom must be directed to the people when the state or people of the state are in crises. The practical knowledge of politics is also part of philosophy. Even if philosopher is not part of the government, it is his responsibility to discern between good and evil, right and wrong, extravagance and proportion, and also to give his verdict about the most virtuous and valuable asset of the state, that is prevailing justice and law and order.

\section{DUTY OF WISEMAN}

Delineating about this responsibility on part of philosopher Cicero (2008), So comments, "I find this most astonishing in the writings of intellectuals; they plead their inability to steer the ship when the sea is calm, because they have never been taught and have never cared to acquire such knowledge; and yet they proclaim that they will take the helm when the waves at their highest. Those gentlemen openly admit, and indeed take great pride in fact, that they have never learned and do not teach anything about how to setup or maintain a government; they think that expertise in such matters does befit learned and philosophical men and should be left to people with practical experience in that sort of thing. So what sense does it make to promise assistance to government only if driven to do by a crises, when they cannot manage a much easier task, namely to take change of government when there is no compelling crises? Even if it were true that the sage does not voluntarily deign to descend to technicalities of statecraft and yet does not shirk that duty if forced by circumstances, I should still think it quite wrong for him to neglect the art of politics; he ought to have everything at his fingertips, for he never knows when he may have to use it". (p.7)

\section{THE CASE OF ASTRONOMY AND POLITICS}

There are several issues which affect the public life. The case of rumors is one example. These issues, when become the talk of the town or people, they then are closely related to politics. As politics covers the every area of public life, so these matters, such as lunar eclipse, solar eclipse and other matters of physical universe, come as discussion among the wise men or philosophers also.

Philosophy is still the queen servant of mankind. Every knowledge has its own philosophy. As every sphere of human knowledge is based on logic, even any sentence is built on logic. However, the source of major philosophies is Greece. Greek philosophers have excelled in every kind of philosophy and under the heading of philosophy; they have developed many fields of knowledge, ranging from geometry to astronomy. An interesting episode by Cicero is cited in "The Republic"; how astronomy affects the politics?. He has collected a 'pride' of intellectuals, enjoying holidays, and doing discussion about the sight of two suns by people. These intellectuals include, 'Tubero', 'Scipio', 'Philus', ‘Africanus', 'Laelius', Manilius', Muelus' (Cicero (2008) One of these wise men, Scipio suggests, :I always think Socrates was wiser. He refused to concern himself with matters of that kind, 
holding that problems about the physical universe were either too enormous for reason to comprehend or else quite irrelevant to his life Cicero (2008) Another wise man Tubero furthering the discussion says, "I don't know why tradition has it, Africanus, that Socrates ruled out all speculation of that kind and confined himself to the study of everyday moral behavior. We can cite no higher authority about him than Plato, can we? Yet in Plato's books, Socrates speaks in many passages in a way which indicates that, even when he is discussing behavior, moral values, and political topics, he is still keen to include arithmetic, geometry and musical theory, just as Pythagoras did".(p.9)

The very case of astronomy, though interesting, but highly serious especially as soldiers or people take omens from celestial bodies. Scipio, Cicero (2008) again expounds in this way. "I remember when my father was consul in Macedonia and we were in camp (I was quite young at that time), our army was troubled with superstitious fear because on a clear night the bright full moon suddenly failed. Galus was then our staff and officer, about a year before he was elected consul. On the next day, without any hesitation, he made a public statement in the camp to the effect that this was not an omen, it had happened then, and would continue to happen at fixed times in the future, when the sun was in a position from which its light could not reach the moon". (p.12)

Scipio, According to Cicero (2008) has also described another incident "something of that kind also happened in the great war which was fought with such ferocity between Athens and Sparta. When an eclipse of the sun brought sudden darkness, and the Athenians' minds were in the grip of Panic, the great Pericles said to have told his fellow-citizen a fact which he had heard from his former tutor Anaxagoras, namely that this thing invariably happened at fixed intervals when the entire moon passed in front of the sum's orb; and so, while it did not occur at every new moon, it could not occur except in that situation. By pointing out this fact and backing it up with an explanation he released the people from their fear. At that time it was new and unfamiliar idea that the sun was regularly eclipsed when the moon came between it and the earth a fact which was reputedly discovered by Thales of Miletus. On a later occasion the point was also noted by our own Animus. He writes that about three hundred and fifty years after the foundation of Rome.

On June the fifth the Moon and night blocked out the Sun',

This shows the worth, significance, stature, peculiarity, esteem and greatness of philosophers in a society.

\section{STATE AND THE LAW}

These matters are directly related to governance and government. If these matters are not dealt with by philosophers, who are the leaders of a certain society, a well-run state may be derailed and meshed up in anarchy which means the loss of law and order and security of the citizens. Plato maintained in his "Republic" and has cited that the first and foremost responsibility of a state is to maintain law and order and protect its citizens. Cicero (2008) also following the lines of Plato, is of the view that "I have set out these points at some length, because in the present work I have planned and undertaken a discussion of the state. To prevent the project from seeming futile, I had, at the outset to get rid of people's scruples about entering the public life. Nevertheless, they should pay attention for a moment and listen to men who enjoy a very great authority and reputation in the highest intellectual circles. Even, if they never actually governed, I still think they did the state some service, because they studied and wrote extensively about it. In fact I note that those whom, the Greeks called 'The Seven Wise Men' in almost every case played a central role in political life. Nor, indeed, is there any occupation which brings human excellence closer to divine power than founding new states and preserving those already founded". (p.7)

\section{NATURE OF STATE AND GOVERNMENT:}

Cicero (2008) furthering the dialogues on the state by Scipio and others and engaging them on the finest debate of history discussed what is the best form of government and so quotes by putting the question from the mouth of Laelius to Scipio, "Those skills which make us fit to serve the community. That, in my 
opinion, is the finest duty that wisdom has, and the greatest proof and function of moral excellence. So then, to make sure that we spend this holiday in discussions that are primarily of benefit to the state, why don't we ask Scipio to tell us what form of government he regards as the best?" (p.17)

The points raised by Laelius are very important, but he should have added, in performance of serving, one should be highly honest, dedicated, devoted and selfless.

Further discussing the issue of the best form of government, as asked by Laelius to Scipio Cicero (2008) he (Scipio) speaks thus, "Well, I can't pretend that there's any subject to which I give more attention than the one which you are suggesting, Laelius. I am aware that every craftsman in his own work, if he is any good, thinks, ponders, and strives for nothing except to improve in that field. I have inherited this task from my parents and ancestors, that is, the supervision and management of the country. So, I suppose I would be admitting that I was lazier than any craftsman, if I devoted less effort to that great art than they do to their little ones. Yet I am not satisfied with what's the foremost and wisest Greeks have left us in their writings about that topic. Nor do I venture to set my opinion above theirs. So, as you listen, I suggest you think of me as not wholly ignorant of the Greek views, nor as ranking them above our own, especially in this field. Think of me rather as one of togawearing people, who has been given a liberal education, thanks to his father's kindly concern, and has been fired from boyhood with a love of learning, but who has, nevertheless, been trained by experience and family much more than books". (p.17)

Scipio has referred to very important things. He states that the books are not the sole teachers but it is the experience and the practical experience which makes one to learn the art of government. He has also talked about the excellence of Greeks in this field of practical politics, but he says that they are not above the Roman thinkers. It's a historical fact that Romans excelled the Greeks in the administration of the government. Greeks were well versed in arts and sciences, but even though they also ruled the Known world, but Roman Empire lasted for more than eight hundred years. The Roman strategy of ruling the world is still not only followed, but considered as the best strategy to govern the people apart from your own country.

Scipio, Cicero (2008) after discussing the nature of discussion, so follows, "well, then, a republic is the property of the public. But a public is not every kind of human gathering, congregating in any manner, but a numerous gathering brought together by legal consent and community of interest. The primary reason for its coming together is not so much weakness as a sort of innate desire on the part of human being to form communities. For our species is not made up of solitary individuals or lonely wanderers. From birth it is of such a kind that, even when it possesses abundant amounts of every commodity". (p.19)

Scipio has delineated the fundamentals of community. He says that human beings by nature are not astrayed.

He identifies the nature of this species and tells that community is formed on common interest, improvised by legality and consensus of the people. He also clearly states that republic is dependent on people, and community is formed on legal consent, and is not based on innate desire of people. He is of the view that it seems to be the compulsion of human beings or this species to live in a community and with integration of the people.

Further Scipio, so suggests, Cicero (2008) these groups, formed for the reason just explained, first founded a settlement in a fixed place for the purpose of building houses. When, with the help of the terrain and their own manual labour, they had made it secure, they called such a collection of dwellings a town or when it had been laid out with shrines and public spaces, a city. (p.19)

Discussing the matter of governance, Scipio, Cicero (2008) elaborates his ideas as such, "So then, every people (Which is a numerous gathering of the Kind described), every state (Which is an organization of the populace), and every republic (Which, as I said, is the property of the public) must be governed by some decision-making process if it is to last; that process must, in the first instance, always come into being for the same reason as that which gave rise to the state. Then this process must be entrusted to one man, or a selected group, or else be carried on by the 'Whole populace. When the supreme authority is vested in one man, we call him a King, and the government of the state is a monarchy, when it is vested in a selected group, that state is said to be ruled by the power of an aristocracy. The state in which everything depends on the people is called a democracy". (p.p.19-20) 
Scipio Cicero (2008) has very clearly defined and distinguished three forms of government. He doesn't claim that one is better than the other and he neither considers one more perfect and flawless than the other. Though he favours monarchy and aristocracy and considers democracy as least desirable, but according to him all these forms of governments may remain stable if greed and wickedness don't prevail and especially in the democratic government these virtues are essential.

Therefore, we can say that in running a state first and foremost thing again is ethics. These ethics as hinted above by Scipio are conjoined very closely in governing a state.

\section{THE QUESTION OF LIBERTY}

The question of liberty of individual or a group is spanned over the history of mankind since the time civic life started. The civic life means civility which is also a concern of ethics. Almost every philosopher or thinker has expounded on the notion of liberty. It seems an unachievable target, because in one way or the other a state or a society is governed by certain laws, which have been agreed with by the masses of any state. The question of liberty is still, even in twenty first century, an imperative. We can say that abiding by the laws of a society, we can trace the element of liberty. If, we break the laws, that mean we have become a danger to the society, state, but also to the other people. But, in other words to follow the laws of a state can lead us to live in a situation of liberty. The modern era of diverse media, of technological innovation, where now we are focusing on developing robotics and also taking benefits after creating the science of artificial intelligence; but all the products of science are aided by advertisement, from single news to the development of hi-tech machines; the question of liberty has changed. Whatever is dictated by media, backed up by advertisement, has created an anxiety in every society present on the globe. But, even in the presence of all these practices, the basics are still valid. As liberty is more related to customs and traditions of any state and governing a society, thereby it is also related to the age old concept of justice. If justice prevails in any society and people don't try to take justice in their hands or do justice by themselves, for the injustice done to them, then we can arrest this era's chaos, anarchy and anxiety.

Taking up the issue of liberty in the background of defending the democracy, Scipio, Cicero (2008) speaks thus, "and the nature of every state depends on the character and will of its ruling body. So, liberty has no home in any state except a democracy. Nothing can be sweeter than liberty. Yet if it isn't equal throughout, it isn't liberty at all. For how can liberty be equal throughout, I will not say in a monarchy, where slavery is evident and unmistakable, but in those states where everyone is free in name only? They register their votes, they bestow military commands and political offices, they are canvassed, and asked to say yea or nay; but they confer what they would have to confer even if they didn't want to do things which they themselves don't have. In spite of being asked for them by others. For they have no share in the supreme power, or in national policy-making, or in legal decisions (those are made by specially appointed judges" (pp.21-22)

Scipio Cicero (2008) continues his dialogue in this manner, "If (the state) leaves the process to chance, it will be overturned as quickly as a ship in which a man chosen by lot from among the passengers had taken over the helm. If however, a free people choose the men to whom it will entrust itself, and if, with a genuine desire for security, it chooses only the best men, then without a doubt the security of such states depends on the policies of aristocrats, especially as nature has decreed not only that men of superior character and ability should be in charge of the less endowed. But also the latter should willingly obey their superiors." (p.23)

Further defending the aristocracy or aristocratic form of government Scipio Cicero (2008) maintains, "But they maintain that this ideal state has been ruined by people who cannot think straight-people who, knowing nothing about worth (Which resides in a few, and is discerned and assessed by a few), imagine that aristocrats are those with large fortunes and possessions or those who belong to famous families. When, as a result of this vulgar misconception, a few with money, not worth, have gained control of the state, those leaders seize the name of 'aristocrats' with their teeth, though lacking any right to it in fact. Money, name, and property, if divorced from good sense and skill in living one's own life and directing the lives of others, lapse into total degradation and supercilious insolence. And indeed there is no more degenerated kind of state than that in which the richest are supposed to be the best. But what can be more 
splendid than a state governed by worth, where the man who gives orders to others is not the servant of greed, where the leader himself has embraced all the values which he preaches and recommends to his citizens, where he imposes no laws on the people, which he does not obey himself, but rather presents his own life to his fellows as a code of conduct?', (pp. 23-24)

Even in this dialogue, the emphasis is on superior character of those who govern, and they should not become victim to greed which leads to degeneration and corruption. It seems that ethics and governance are two sides of a single coin. If the dimension of ethics is ignored, degeneration occurs. Can we leave this greed and corruption phenomena to human nature? As even the men of superior character have been falling in this trap. This seems to be utopian idealism on part of the wise man Scipio, selected by Cicero to point out and state the nature of forms of government. Ever since the beginning of the governance, it seems that power corrupts the powerful, because it looks that within the paradigm of power, the flair of power makes the leader, or leaders as he or they are the sole owner of everything of the state, therefore, they become corrupt, which is a phenomenon rooted in the psychology of human beings and their circumstances. The desire of excess and extravagance is present in every human being. And there is where training of character is required, which should make the people and the leaders to restrict themselves only to take that much which is needed and leave rest for the needs of others. It is very difficult to be contented and take that much share from the society which is sufficient for oneself. And also in every society, there should be an equal opportunity for all to raise and exploit their energy and earn.

Again asked by Laelius to Scipio Cicero (2008) which form of the government is the best, he (Scipio) answers so, "You are right to ask which of the three I must approve of, for I do not consider any of them ideal by itself. Rather than any one of the separate types, I prefer mixture of all three. But if one has to be preferred in its pure form, I would prefer monarchy........ (In the last few lines of this section the text is defective). The name of King is like that of father, in that a King takes thought for his subjects as if they were his children, and looks after them more conscientiously than..... that they are supported by the dedication of one man, the best and most highly esteemed." (p.25)

Further pondering on this issue Scipio, Cicero (2008) explains, "Here now are the aristocrats, who claim to perform this function more effectively, claiming there is more good sense in a group than in an individual, and yet also the same degree of fairness and reliability. But here come the people, shouting at the top of their voices that they obey neither an autocrat nor an oligarchy; that nothing is sweeter than liberty, even to wild animals, and that this blessing is denied to anyone who serves a King or an aristocracy. Accordingly King attract as by affection, aristocracies by good sense, and democracies by freedom. So in comparing them it is hard to choose which one likes the best." (p.25)

Though Scipio has said that it is difficult to choose the best form of government, yet he favors monarchy. Why is it so? The answer is very simple. We can't transcend from our age. As the slavery ended in Nineteenth Century, after the society became industrial. This makes us to see that history and specially the history of mankind has its own movement. Nietzsche termed the course of history as cyclic. Hegel developed the concept of dialectics, of which the first proponent is Socrates..... And Marx interpreted the course of history, in the domain dialectical materialism, as spiral. There is also a fact that history moves forward than individual thinking. This is called as "lagging consciousness". The movement of history is an independent variable like time. Every age of history doesn't allow you to surpass its notions, because man and his thinking are determined.

Scipio, Cicero (2008) expounding on the notion of constitution says, "A state should possess an element of regal supremacy, something also should be assigned and allotted to the authority of aristocrats, and certain affairs should be reserved for the judgment and desires of the masses. Such a constitution has, in the first place, a wide spread element of equality which free men cannot long do without. Secondly, it has stability; for although those three original forms easily degenerate into their corrupt versions (producing a despot instead of a King, and oligarchy instead of an aristocracy, and a disorganized rabble instead of a democracy), and although those simple forms often change into others, such things rarely happen in a political structure which represents a combination and a judicious mixture-unless, that is, the politicians are deeply corrupt. For there is no reason for change in a country where everyone is firmly established in his own place, and which has beneath it no 
corresponding version into which it may

suddenly sink and decline.” (pp. 32-33)

Scipio has clearly stated about the three forms of government and constitution. He is of that view the constitution should hold the element of equality. But he also emphasizes, that, if corruption overrules these systems, then King Turns into a despot and aristocracy into oligarchy, and democracy into anarchy.

The world now is immersed in anarchy. We are now in favor of democracy, but this is not true democracy. That's the reason, due to absence of true democracy across the globe; the world is speedily heading towards the worst war. The democracy today is in the degenerated form, and degenerated democracy is anarchy. Again Scipio has tied the function of state with ethics by insisting that in all forms of government corruption should not occur.

The most vicious aspect of our democracies of present day is corruption and of every kind. Cicero (2008) in (Book 6) of the Republic, states about the conflict and anarchy as such, "......and in times of civil conflict, when soundness is more important than numbers, I think citizens should be assessed rather than counted (Nonius 3.836).” (p.85)

Further Cicero (2008) maintains, "For our lusts are set over our thoughts like cruel mistresses, ordering and compelling us to do outlandish, things. As there is no way in which they may be appeased or satisfied, once they have inflamed a person with their seductive charms they drive him to every sort of crime (Nonius 3.686)." (p.85)

Cicero (2008) admires the foundation of Rome by the great Romulus at the advantageous site of the great river Tiber and for these reasons, "After this splendid achievement, Romulus, first thought, we are told, was to found a city by means of augry and to establish a political community. He chose an incredibly advantageous site for the city-a thing which has to be planned with careful foresight by anyone trying to create a permanent community. He did not move it to the coast, though with troops and resources of that size he could easily have marched into the territory of the Rutulians and Aborigines; or he could have started a new city at the mouth of the Tiber, where King Ancus founded a colony many years later. With his exceptional imagination the great man realized clearly that coastal sites were not particularly suitable for cities founded in the hope of permanence and power, first because coastal sites were exposed to numerous, and also unforeseeable, dangers. For, in the case of an inland settlement, advance warning is given of an enemy's approach, not only when it's expected but also when it isn't, by many indications, including a certain amount of unavoidable noise and din. No enemy can come across country, at whatever speed, without our knowing that he's there, and also who he is and where he comes from. But a maritime, naval enemy can be upon before anyone knows he is on the way; and when he comes he doesn't advertise his identity or his nationality or even his intentions, there is no means of discerning or inferring even whether he is friend or foe." (p.36)

\section{CONCLUSION}

Cicero in his exceptional treatise 'The Republic' has exhaustively seen the various issues about the functioning of the state, its laws, and how constitution is developed, maintained and tied with ethics? Moreover, throughout his book we have seen that the nature of the state, whether in the form of monarchy, aristocracy or democracy, must be built on the solid and sound grounds of ethics.

The great nations of history get degenerated, if they are not judicious; and their leaders are corrupt and greedy.

Regarding the foundation of any state, Cicero has pointed out that river side state is more advantageous. As he is of the view that sea people and civilizations are prone to corruption and then easily get degenerated. This is the reason, why he admires Romulus, the son of Mars, establishing the state, across the great river Tiber. As Roman civilization was the sister civilization of Greek, and Greek in turn owed much to Egyptians, who were indebted to Babylonians, therefore Cicero might have also thought that river-side civilization is the best. And, moreover, he has also given reasons for establishing river-side civilization and, how it is advantageous?.

The river flows from the heart of the mountain. The mountain is not only its source, but its guard also. Wherever the river goes mountain guards it. The same flow, same generosity and same sturdy excellence is found in the people like river, who live along the banks of the river.

The richness of the river weaves the legend and the river in itself is a natural constituent of civilization.

\section{REFERENCES}

[1] Cicero, (2008) The Republic and The Laws (N.Rudd, Trans) Oxford World's Classics, New York. 